\title{
Should UK medical students complete a PhD during their undergraduate studies?
}

This article was published in the following Dove Press journal:

Advances in Medical Education and Practice

\section{Osama Hamid \\ Rawa Burhan \\ Ling Him Cheng}

Faculty of Medicine, Imperial College London, London, UK
Correspondence: Osama Hamid Faculty of Medicine, Imperial College London, Exhibition Road, South Kensington, SW7 2AZ, London, UK Email osama.hamidI3@imperial.ac.uk

\section{Introduction}

Having a $\mathrm{PhD}$ (Doctor of Philosophy) degree is very beneficial for a clinician. It instills important scientific skills and methods that are not only useful within academia but also allow continued professional development and understanding of the continued advancements in the field of medicine. As well as this, in some competitive specialties such as cardiology, having a postgraduate degree is often a minimum requirement for application. ${ }^{1}$

Most people who complete a $\mathrm{PhD}$ do so by taking time out of their specialty training. However, a possible alternative is to opt for an $\mathrm{MB} / \mathrm{PhD}$ program at medical school, where a student undertakes a $\mathrm{PhD}$ after completing an intercalated degree and, on its completion, resumes their medical training. In the UK, four medical schools offer this institutionally, while further 17 schools allow students to interrupt their studies and complete a PhD. ${ }^{2}$ Deciding on whether to do a $\mathrm{PhD}$ at medical school or wait until further on in the medical career is an important decision, and one which should not be taken without due consideration of the strengths and weaknesses of each option.

An advantage of doing a $\mathrm{PhD}$ while at medical school is that one can get it out of the way early and not disrupt postgraduate training, particularly since undergraduates tend to be young and have less financial and familial responsibilities. Additionally, graduating with an $\mathrm{MB} / \mathrm{PhD}$ gains five points in the foundation program application for newly qualified doctors, which increases chances of obtaining the preferred foundation job. ${ }^{3}$

A disadvantage of doing a $\mathrm{PhD}$ as an undergraduate is that 3-4 years are spent out of medical study. This could prove to be a problem when resuming the course since aspects of preclinical medicine, basic clinical skills, and history taking effectively have to be "re-learnt". Additionally, it is possible that the $\mathrm{PhD}$ will not be relevant to the field of medicine the student eventually chooses to specialize in, although the scientific skills gained during it will be transferable. Doing an MD (Doctor of Medicine), a shorter 2-year postgraduate qualification, is another option, and one that can only be completed after medical school.

\section{Conclusion}

As $\mathrm{PhDs}$ are increasingly becoming more important for clinicians to have, the decision as to when to undertake them should not be taken lightly. It is essential that the student looks at their own particular circumstances and researches thoroughly whether doing 
a $\mathrm{PhD}$ will be advantageous to their planned career route. It is also important to consider the impact of interrupting their studies and to weigh this against the advantage of beginning a medical career with a significant postgraduate qualification already under the belt.

\section{Disclosure}

The authors report no conflicts of interest in this work.

\section{References}

1. BMJ Careers [webpage on the Internet]. A Closer Look at a Career in Cardiology. UK: BMJ Careers; 2015 [cited 2017 Dec 11]. Available from: http://careers.bmj.com/careers/advice/A_closer_ look_at_a_career_in_cardiology.

2. Barnett-Vanes A, Ho G, Cox TM. Clinician-scientist MB/PhD training in the UK: a nationwide survey of medical school policy. BMJ Open. 2015;5(12):e009852.

3. UK Foundation Programme Office. UK Foundation Programme 2018 Applicants' Handbook. Birmingham: 2017.

\section{Publish your work in this journal}

Advances in Medical Education and Practice is an international, peerreviewed, open access journal that aims to present and publish research on Medical Education covering medical, dental, nursing and allied health care professional education. The journal covers undergraduate education, postgraduate training and continuing medical education including emerging trends and innovative models linking education, research, and health care services. The manuscript management system is completely online and includes a very quick and fair peer-review system. Visit http://www.dovepress.com/testimonials.php to read real quotes from published authors.

Submit your manuscript here: http://www.dovepress.com/advances-in-medical-education-and-practice-journal 